\title{
Extraction of Aluminium Sulphate and Copper Sulphate from Printed Circuit Board as E- Waste
}

\author{
Mohammad Tofayal Ahmed*1, Md Golam Firoz ${ }^{1}$, Md Shajidul Islam ${ }^{1}$, Md Yeasir Hasan ${ }^{1}$ \\ Department of Petroleum and Mining Engineering, Jashore University of Science and Technology, Jashore ${ }^{1}$
}

\begin{abstract}
With the continual modernization, researchers and scientists are very conscious about the environmental issues. The E-waste which is relatively recent addition to the waste stream in the form of discarded electronic and electric equipment is getting increasing attention from policy makers as the quantity being generated rising rapidly. The consumption of e-waste has been exponential in the last two decades. The developing countries are facing huge challenges in the management of e-waste which are either internally generated or imported illegally as used goods in an attempt to bridge the so-called "digital divide". E-waste contains hazardous constituents that may negatively impact the environmental and affect human health if not properly managed. On the other hand, e-waste contains up to 60 metals including platinum, gold, silver, copper, aluminium, palladium, iron and other valuable metals. Considering these two facts along with the resource management strategy has been committed to extract precious metals from Printed Circuit Board (PCB) of e-waste. In this study, Printed Circuit Board (PCB) are collected from the motherboards of waste computers and performing several reactions in a chemical lab. $\mathrm{Al}_{2}(\mathrm{SO})_{4}$ has been prepared by using sulfuric acid and potassium hydro-oxide and $\mathrm{CuSO}_{4}$ prepared by using nitric acid and sulfuric acid. In this preparation process the top most priority is placed on the environment friendly issues. This study will very helpful in the proper management of ewaste and reservation of our resources which are limited.
\end{abstract}

Keywords: Aluminium, Copper, Electrochemical recycle, E-Waste, Eco friendly, Environment

\section{INTRODUCTION}

The higher growth of people with advanced global economy leads on large use of electronic devastate, or e-waste (WEEE) that indicate to heat alternate of equipment, computer screens, lamps as well as other different IT tools which have discarded through their owners which is considered as waste lacking of re-using and directly influenced the environmental (the soil pollution) and it is the another major cause reduction of natural resources [1,2]. The electrical as well as electronic tools (as a result of e-waste from these products) are considered the enlargement of the technology in equivalent theme of the urbanization and industrialization in last and present decades [3]. From the topical scenario goes that approximately 46.8 million metric tons of e-waste have been manufactured in around the globe in 2018 which is over weight of 45 million metric ton of Eiffel Towers and it is very apprehension that it crosses the limit to 54.2 million metric tons before [4, 5]. Approximately 46.7 million metric tons of e-waste was produced in 2018 that is correspondent to $6.1 \mathrm{~kg}$ per individual person which was $5.8 \mathrm{~kg}$ per individual person at the year 2016. This rate will be enlarged to 54.2 million tons and per individual person $6.8 \mathrm{~kg}$ at 2021. This was reported by Global E-Waste Monitor (GEWM) [6, 7].

However, maintaining the policy as well as the parameter of the government, the procedure of arranging valuable substances from E-waste is very difficult to assemble. The abrupt dispensation can lead to horrible possessions consequential on health risk again it is the contagion of the surroundings of environment. It is generally responsible for polluting the groundwater and soil also [8]. On the contrary, E-waste is considered the copious supply of different pedestal materials or the metallic body likely as: $\mathrm{Cu}, \mathrm{Zn}, \mathrm{Al}$; $\mathrm{s}$ well as other valuable metallic bodies such as: $\mathrm{Au}, \mathrm{Ag}$ and $\mathrm{Pt}[9,10]$. That is predictable that an archetypal considerable circuit board is consist of $40 \%$ of metal substances, $30 \%$ of Plastics substances and 30\% of ceramics of its total weight (Waste Printed Circuit Boards (WPCBs) [11, 12].

In different country like Bangladesh, the instruction of e-waste is still in its preliminary situation. According to date and relevant of waste, there is no actual system of parameter for running of electronic waste into our valuable utilization [13].It also indicated that it is a considered a new recycling process from the WEEE.As a result, in generally our industry is not capable of the recycling of capacity or the skill to development of large amount WEEE. Majorly the WEEE processes do not suggest the precious recovery cycle because they are focused only on the taking out of valuable component to component easier to separate, departure away the non-important part or major problematical apparatus $[14,15]$. Which components represent there has no financial rate or very tiny financial rate and has huge risk of human health and environment that components are called non-valuable components. Examples these: plastic part of 


\section{International Advanced Research Journal in Science, Engineering and Technology}

Vol. 6, Issue 11, November 2019

circuit, cathode ray tubes. In the same contrary, the components represent the valuable part of circuit which fabricates different metallic bodies containing copper and gold, zinc and others [16].

Actually, in last decades, the quantity of CRT monitors as the form of television as well as computers is considered as the replacement Liquid Crystal Displays (LCD) The prediction goes that around 8.5 thousand tons televisions as well as computer monitors are redundant in the south Asia every year. These same circumstances are found in other industrial, developed with developing state in the world. So, this ratio indicated that re cycle must be needed [17]. As a result, during the last decades, numerous explorations have been planned or aimed at the innovation of reasonable techniques withdrawal for precious metallic substances. This process is continuing from the last several decades. Basically, these processes are divided in different ways such as physical, hydrometallurgical, bio metallurgical, and hydrometallurgical as well as electrochemical procedures. Here used the electrochemical techniques which are considered the most competent because lower discharge of poisonous gases with lower volatile metals, lower energy of expenditure, and small waste production with its easier operational circumstances.

\section{MATERIAL AND METHODS}

\section{A. Aluminium Sulphate}

A.1 Sample preparation: In this technique, computer mother boards through 2000 to 2014 were collected randomly from computer repaying shop to be used this research. In this exploration used moderately newer motherboard because high older contains lower proportion of metallic bodies. Eradicate several aluminium parts from the capacitor on the plastic pieces by using the shredder (Ray Machine Company). After removal these e-waste takes a lower part from the higher one. Here used aqua regia the solution of $\left(3 \mathrm{HCl}+1 \mathrm{HNO}_{3}\right)$ for good precipitation of the waste. $23.5 \% \mathrm{Cu}, 1.85 \%$ $\mathrm{Al}, 2.15 \% \mathrm{Zn}, 2.65 \% \mathrm{~Pb}$ after the last stage of precipitation are found from this process. For the waste performance highly, we need Aluminium metal, Potassium hydro-oxide (KOH), Sulfuric acid $\left(\mathrm{H}_{2} \mathrm{SO}_{4}\right)$, Filter paper, Funnel, Beaker.

A.2 Aluminium Sulphate Extraction Procedure: Scrap aluminium piece that about weights 1.6grams. To remove the paint and lacquer scrape both sides of the piece (for the reason of dissolving process greatly, and give a more accurate starting mass). Put of the pieces of aluminium in a $250-\mathrm{mL}$ beaker. Under the fume hood, add $62 \mathrm{~mL}$ of $1.4 \mathrm{M}$ potassium hydroxide solution to the beaker. Heating the mixture on the electric hot plates provided it about take 30 minutes to dissolve. During the reaction, the mixture will turn dark grey due to silicon impurities, residual paint, plastic liners, etc. No more than thirty minutes should be required to dissolve the sample. The reaction is complete when the evolution of hydrogen ceases. Then filtering the cooled solution to remove any solids remaining Discard the dark solid trapped in the filter paper and Transfer the solution to a clean 250 -mL beaker. If the beaker feels warm, placing it in an ice water bath or in cooler. Slowly and carefully, stir in $30 \mathrm{~mL}$ of $9 \mathrm{M}$ sulfuric acid. Initially noticed that the formation is white, gelatinous aluminium hydroxide precipitates. Collect to aluminium hydroxide as precipitate. As added more of the sulfuric acid, will be noticed the evolution of heat and the dissolving of the precipitate. The procedure of Aluminium Sulphate extraction from E-waste showing in figure 2.
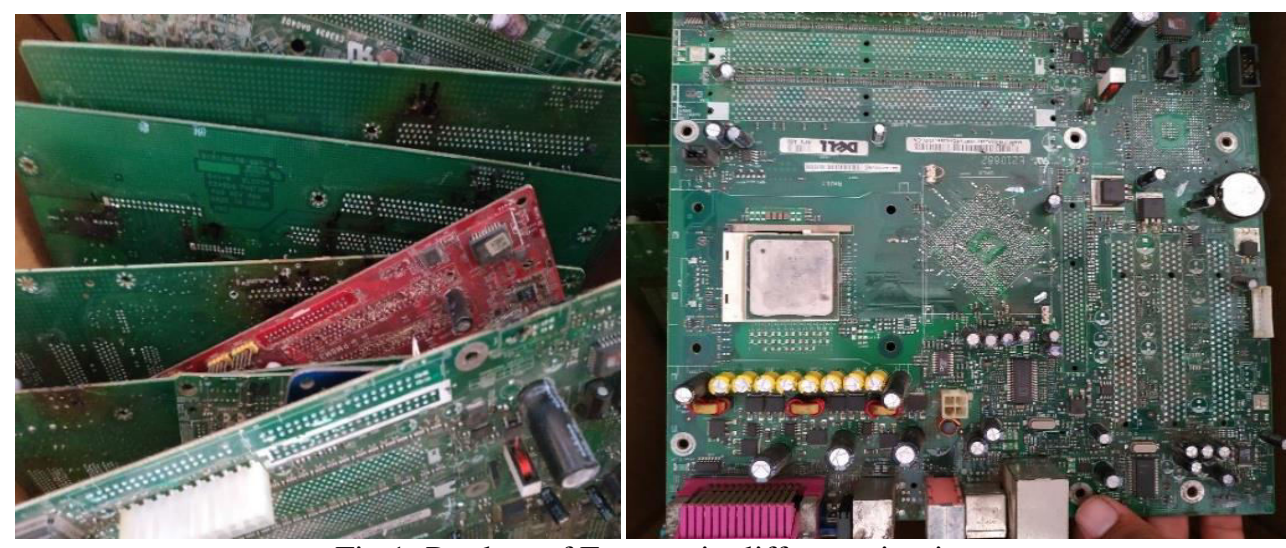

Fig 1: Product of E-waste in different circuit.

\section{B. Copper Sulphate $\left(\mathrm{CuSO}_{4}\right)$}

B.1 Sample Preparation: Eradicate several aluminium parts from the capacitor on the plastic pieces by using the shredder (Ray Machine Company). After collecting the part of copper metal in lower weights than it is dissolved. Avoid the contamination here use the sample was digested in an aqua regia solution $\left(3 \mathrm{HCl}+1 \mathrm{HNO}_{3}\right) . \mathrm{Chemical}$ 


\section{International Advanced Research Journal in Science, Engineering and Technology}

Vol. 6, Issue 11, November 2019

masterpiece of the e - waste we found that moderately contain $23.5 \% \mathrm{Cu}, 1.85 \% \mathrm{Al}, 2.15 \% \mathrm{Zn}, 2.65 \% \mathrm{~Pb}$ after the last stage of precipitation. The lower rating of $\mathrm{Cu}-\mathrm{Al}$ comportment of Sulphate investigation was applied as the high growth of substrate for the enlargement of the action of the microbes. For the sample preparation here used mainly copper metal, Nitric acid $\left(\mathrm{HNO}_{3}\right)$, Sulfuric acid $\left(\mathrm{H}_{2} \mathrm{SO}_{4}\right)$, Beaker, Glass rod, Funnel, Filter paper.

B. 2 Copper Sulphate $\left(\mathrm{CuSO}_{4}\right)$ Extraction Sulphate Procedure: Take $3.5 \mathrm{gm}$ copper metal in a beaker by using weight

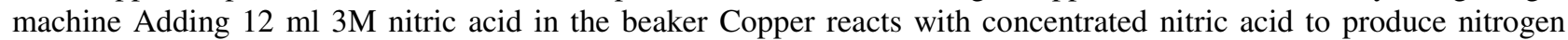
dioxide and with dilute nitric acid to yield nitric oxide. The reaction mixture is warmed in the hood for 20 minutes If any metal remains undisclosed, is removed by decantation or filtration. Here added $15 \mathrm{~mL}$ of $9 \mathrm{M}$ sulfuric acid to the solution. The procedure of Copper Sulphate Extraction Procedure From E- Waste given at figure 3.

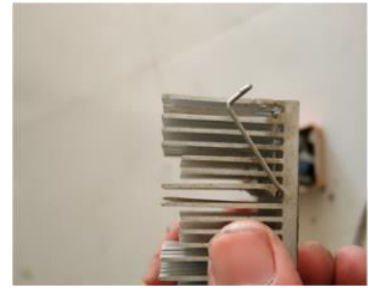

Aluminium metal

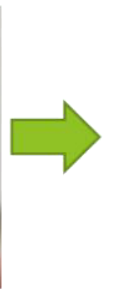

Weighting Aluminium

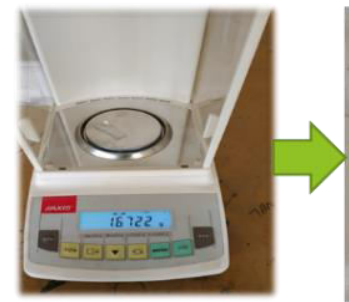

Reaction with potassium hydro-oxide

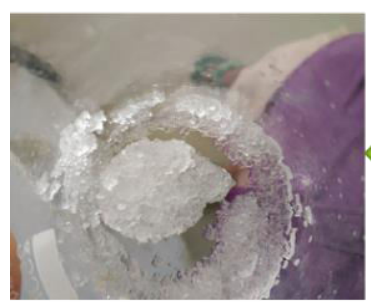

Aluminium sulphate prepared

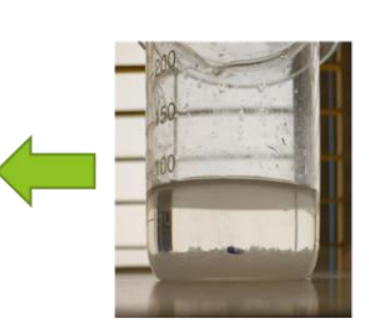

Aluminium sulphate precipitating

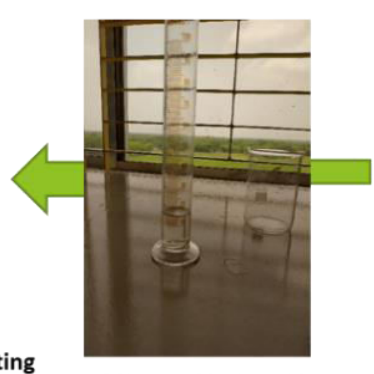

Adding sulfuric acid

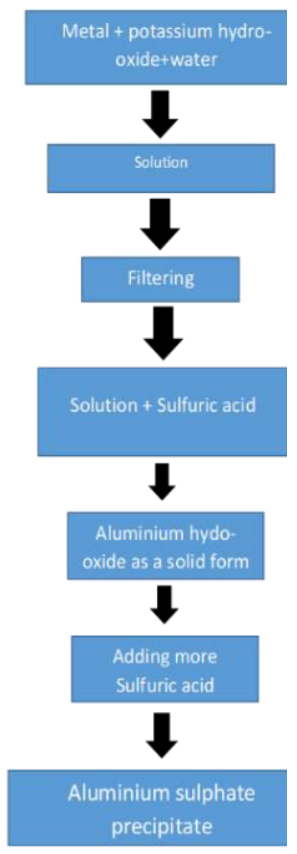

Fig 2: Aluminium Sulphate extraction from E-waste.

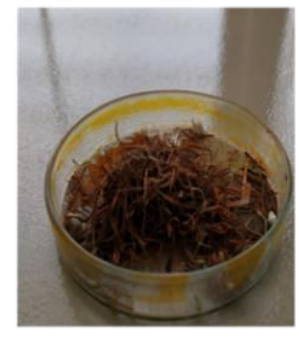

Copper metal

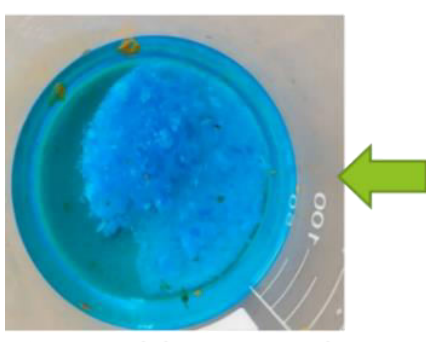

Copper sulphate prepared
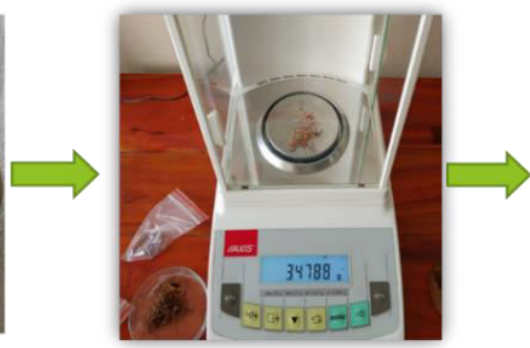

Weighting metal copper

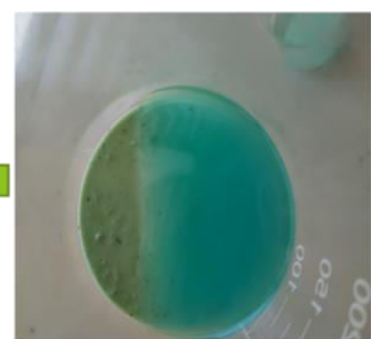

Copper sulphate precipitating
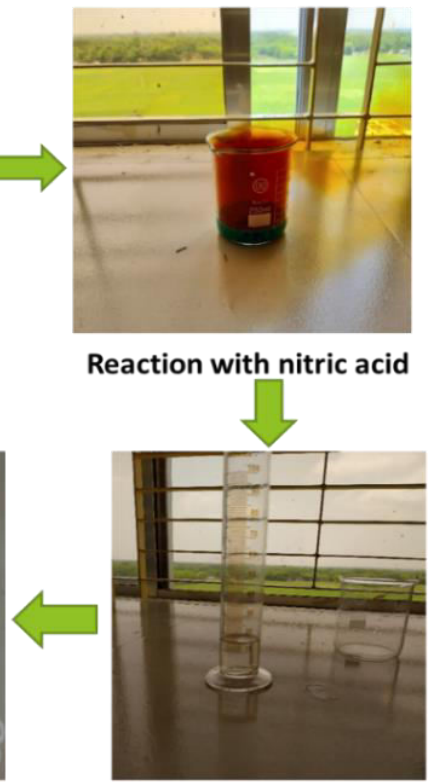

Adding sulfuric acid

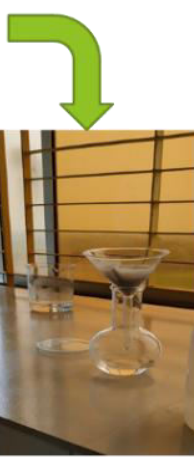

Filtering solution

Fig 3: Copper Sulphate Extraction Procedure From E- Waste.

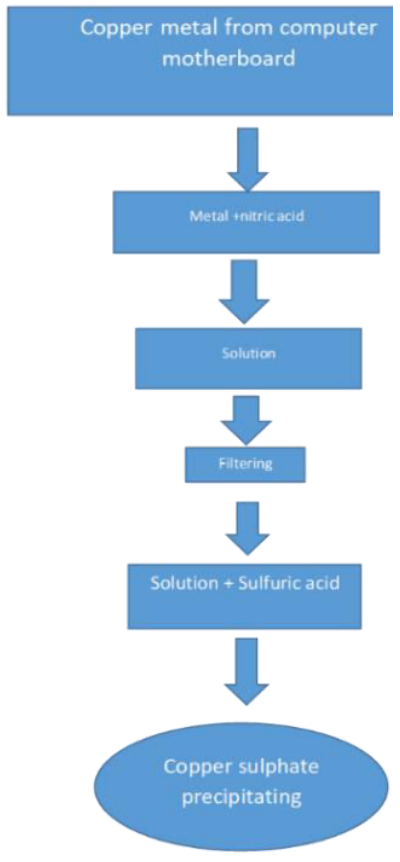




\section{RESULT AND DISCUSSION}

Recovered amount of Aluminium sulphate $\mathrm{Al}_{2}\left(\mathrm{SO}_{4}\right)_{3}$ and Copper Sulphate $\left(\mathrm{CuSO}_{4}\right)$ shown in figure 4 and figure 5 .

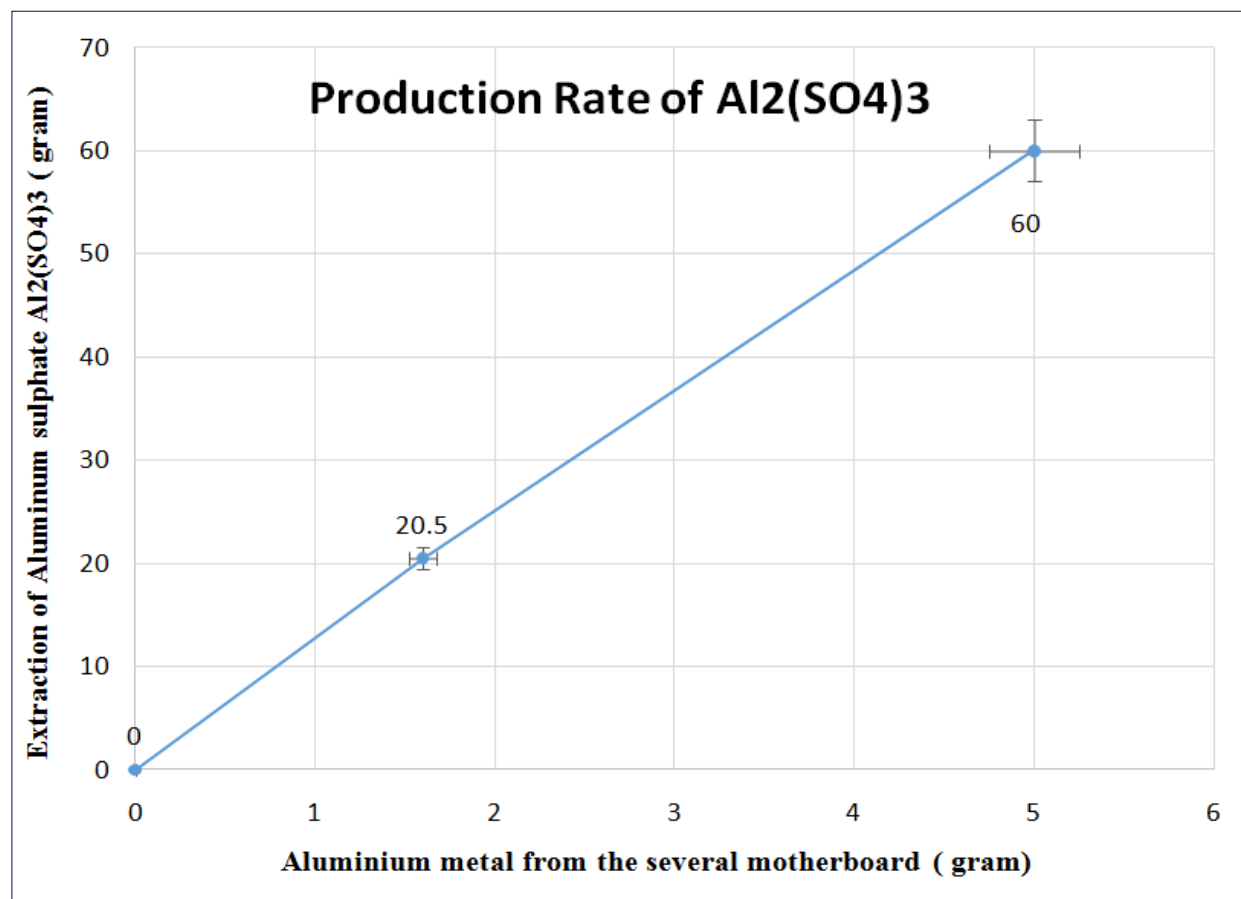

Fig 4: Recovered amount of Aluminium sulphate $\mathrm{Al}_{2}(\mathrm{SO} 4)_{3}$

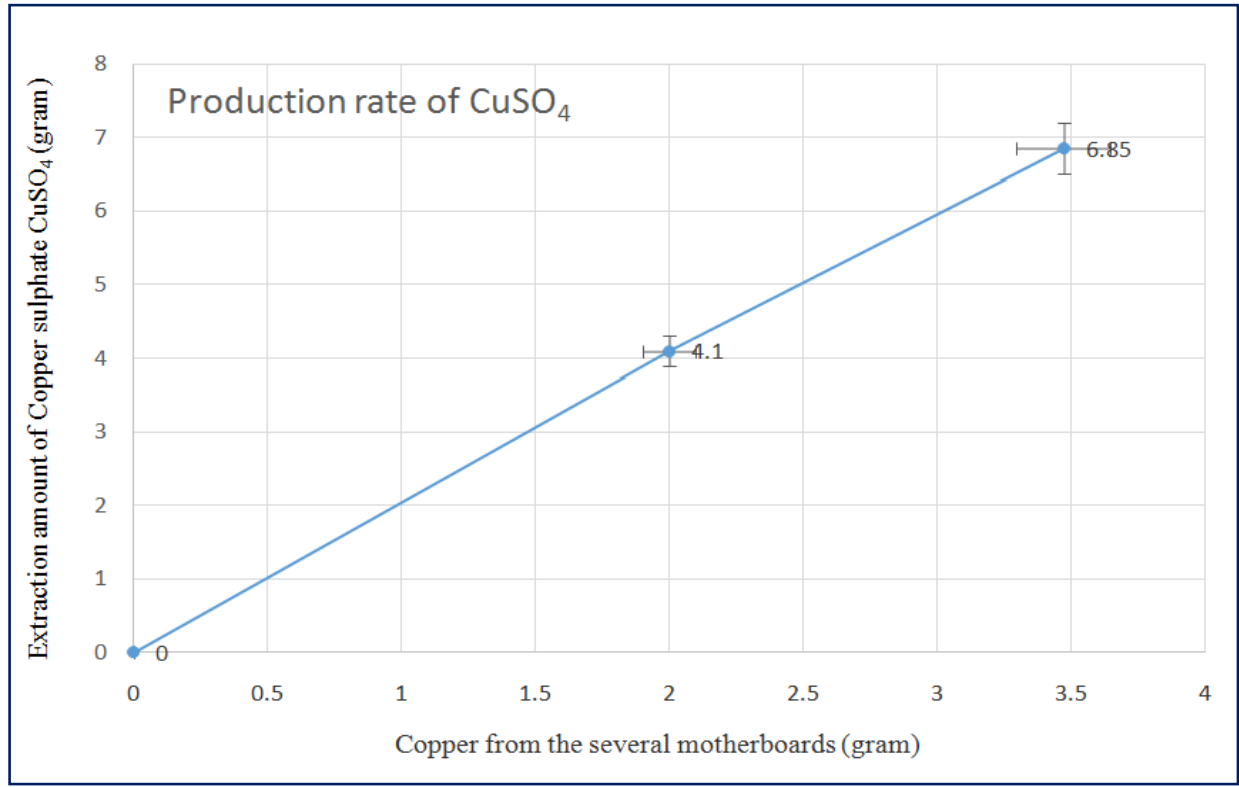

Fig 5: Recovered amount of Copper Sulphate $\left(\mathrm{CuSO}_{4}\right)$

The first step of $\mathrm{Al}(\mathrm{s})$ dissolution in aqueous $\mathrm{KOH}$ is a process of an oxidation-reduction or redox reaction. The oxidation number of $\mathrm{Al}$ metal is +3 and the $\mathrm{H}$ in aqueous $\mathrm{KOH}$ is decrease from an oxidation number of +1 to 0 in the hydrogen gas. There is a complex ion $\mathrm{Al}(\mathrm{OH})^{4-}$ ion is created called "aluminates." The reaction between aluminates ion and Sulfuric acid is occur an acid-base reaction in which the $\mathrm{H}+$ ions from the sulfuric acid neutralize the base $\mathrm{Al}(\mathrm{OH})^{4-}$. At the beginning of the reaction, a gelatinous, white thick, precipitate of aluminium hydroxide $\mathrm{Al}(\mathrm{OH})_{3}$ was formed and as more $\mathrm{H}_{2} \mathrm{SO}_{4}$ acid is added into the precipitate dissolved.

The following equations show the complete sequence of reactions, Reaction of aluminium metal with $\mathrm{KOH}$ (the dissolution step) 


\title{
International Advanced Research Journal in Science, Engineering and Technology
}

\author{
Vol. 6, Issue 11, November 2019
}

Initially addition of cone sulfuric acid in the solution (precipitation of $\left.\mathrm{Al}(\mathrm{OH})_{3}\right)$

$$
2 \mathrm{KAl}(\mathrm{OH})_{4}(\mathrm{aq})+\mathrm{H}_{2} \mathrm{SO}_{4}(\mathrm{aq}) \rightarrow 2 \mathrm{Al}(\mathrm{OH})_{3}(\mathrm{~s})+\mathrm{K}_{2} \mathrm{SO}_{4}(\mathrm{aq})+2 \mathrm{H}_{2} \mathrm{O}(\mathrm{l})
$$

Further addition of more cone sulfuric acid into $\mathrm{Al}(\mathrm{OH}) 3$ (dissolving of $\left.\mathrm{Al}(\mathrm{OH})_{3}\right)$

Finally, $\mathrm{Al} 2(\mathrm{SO} 4)_{3}$ has prepared

$$
2 \mathrm{Al}(\mathrm{OH})_{3}(\mathrm{~s})+\mathrm{H}_{2} \mathrm{SO}_{4}(\mathrm{aq}) \rightarrow \mathrm{Al}_{2}(\mathrm{SO} 4)_{3}(\mathrm{aq})+6 \mathrm{H}_{2} \mathrm{O}(\mathrm{l})
$$

The copper turnings are heated with nitric acid HNO3 in an iron pan until all oily matter is burned off and the metal has become coated with copper oxide. Then concentrated sulfuric acid added into the solution. Copper metal is oxidized to an oxidation number +2 and react with nitric acid, $\mathrm{HNO} 3$ and produce $\mathrm{Cu}^{2+}$ ions.

The nitric acid is creating nitrogen dioxide (NO2) which is a poisonous gas brown in color with an irritating odor.

$$
\mathrm{Cu}(\mathrm{s})+4 \mathrm{HNO}_{3}(\mathrm{aq}) \longrightarrow \mathrm{Cu}\left(\mathrm{NO}_{3}\right)_{2}(\mathrm{aq})+2 \mathrm{NO}_{2}(\mathrm{~g})+2 \mathrm{H}_{2} \mathrm{O}(\mathrm{l})
$$

With the hot and concentrated acid, the product will be copper Sulphate.

Finally, the $\mathrm{CuSO}_{4}$ will be prepared.

$$
\left.\mathrm{Cu}\left(\mathrm{NO}_{3}\right)_{2}+\mathrm{H}_{2} \mathrm{SO}_{4} \text { (hot, conc. }\right)=\mathrm{CuSO}_{4}+2 \mathrm{HNO}_{3}
$$

\section{CONCLUSION}

Here the recycling process are accepted by the by applying the electrochemical psychotherapist which help to the extraction of $\mathrm{Al}$ and $\mathrm{Cu}$ salt in a lower cost and suitable for use. By this process we collect our extraction or our main product as a cupper and aluminums Sulphate. This investigation provides an impression of concerning the momentous technical progresses of rising worldwide to recuperate the waste and divide extraordinary of the glove. It also changes the rudiments replacement of these types of the secondary resources. E-waste, the secondary resources, will contain significant metals as a reserve and also preferable for the environment technologies. Enlargement the ecology gracious with charge efficient techniques for prospective recuperation and partition of rare-earth metallic bodies from these types resources which are considered secondary basis and these are counted the only approach to equilibrium of supplying catastrophes and prospect of future issues. This process is very vulnerable for producing the different metallic bodies in these waste able products in developed and developing country like Bangladesh.

\section{ACKNOWLEDGMENT}

My sincere acknowledgement with thanks to Dr. Aminul Islam, Director Clean Energy and CO2 Capture lab. for his special support during chemical test and permission to use the laboratory.

\section{REFERENCES}

[1]. Willner, J. and A. Fornalczyk (2013). "Extraction of metals from electronic waste by bacterial leaching." Environment Protection Engineering 39(1): 197--208.

[2]. Khaliq, A., et al. (2014). "Metal extraction processes for electronic waste and existing industrial routes: a review and Australian perspective." Resources 3(1): 152-179.

[3]. David, E., and J. Kopac. "Aluminum recovery as a product with high added value using aluminum hazardous waste." Journal of hazardous materials 261 (2013): 316-324.

[4]. Silvas, Flávia PC, et al. "Printed circuit board recycling: physical processing and copper extraction by selective leaching." Waste management 46 (2015): 503-510.

[5]. Choate, W.T. and Green, J.A.S., U.S. Energy Requirements for Aluminum Production: Historical Perspective, Theoretical Limits, and Current Practices, U.S. Department of Energy, February 2007.

[6]. Damgaard, A., Larsen, A.W., and Christensen, T.H., Recycling of metals: Accounting of greenhouse gases and global warming contributions, Waste Manage. Res., 27, 773, 2009.

[7]. Dias, Pablo, et al. "Recycling WEEE: extraction and concentration of silver from waste crystalline silicon photovoltaic modules." Waste management 57 (2016): 220-225.

[8]. Borner, G., Secondary scrap demand for aluminum, presented at Platts Metals Week Aluminum Symposium, Fort Lauderdale, FL, Jan17, 2012.

[9]. Musa Aliyu . "Synthesis \& Analysis of Potassium Aluminium Sulphate (Alum) from Waste Aluminium Can "Vol 1, Issue 8, Oct 2014, PP1-6

[10]. Zhu, Nengwu, et al. "Bioleaching of metal concentrates of waste printed circuit boards by mixed culture of acidophilic bacteria." Journal of hazardous materials 192.2 (2011): 614-619.

[11]. Park, Seong Soo, et al. "Synthesis of hydrated aluminum sulfate from kaolin by microwave extraction." Journal of the American Ceramic Society 83.6 (2000): 1341-1345.

[12]. Kuczyńska-Łażewska, Anna, et al. "Recovery of silver metallization from damaged silicon cells." Solar Energy Materials and Solar Cells 176 (2018): 190-195.

[13]. David L. Heiserman, Exploring Chemical Elements and their Compounds. New York: TAB Books, 1992, p. $118-121$.

[14]. Luo, Z. and Soria, A., Prospective study of the world aluminium industry, JRC Sci. Tech. Rpt., EUR 22951, February 7, 2008.

[15]. M. Kalmar. Proceedings of the Eumpean Surface Treatment of Aluminimn, ES'I'AL Istanbul. 2000. PP98-132.

[16]. Mohamed, M. A., M. E. Kassim, and E. A. El-Katatny. "Optimization of the extraction of aluminum sulfate and ammonium aluminum sulfate alums from aluminum dross tailings." Journal of materials research 13.4 (1998): 1075-1083.

[17]. Zheng, Jie, et al. "Hollow aluminum particle in eddy current separation of recovering waste toner cartridges." ACS Sustainable Chemistry \& Engineering 5.1 (2016): 161-167. 